\title{
Some Observations on Wrongfulness, Responsibility and Defences in International Law
}

\author{
Jure Vidmar ${ }^{1}$
}

Published online: 14 November 2016

(c) The Author(s) 2016. This article is published with open access at Springerlink.com

\begin{abstract}
In this article, I argue that international law has a major structural crack: the limited international legal capacity of non-states, and a high threshold of attribution to states. A great deal of international conduct thus remains unregulated. I further explain that this is not only a gap in responsibility but in fact a gap in international legal regulation. The law of international responsibility overlaps with the law of international legal capacity. For the most part, it is thus only states and international organisations which are even conceptually able to violate international law directly. If a certain conduct is not attributable to them, it will not be internationally wrongful. I also suggest that the division between the primary and secondary rules of international law is confusing and arbitrary, and certainly should not be understood as a sequential order. In the conclusion I argue that scholarship has been perhaps too preoccupied with addressing certain symptoms of the 'great structural crack' in international law, while the real problem lies in the unclear concept of international legal capacity.
\end{abstract}

Keywords International legal capacity $\cdot$ State responsibility $\cdot$ International wrongfulness · Attribution · Primary and secondary rules · Justifications and excuses internationally

This paper is a modified version of my inaugural lecture as Professor of Public International Law, delivered at Maastricht University on 27 May 2016.

Jure Vidmar

jure.vidmar@maastrichtuniversity.nl

1 Maastricht University, Maastricht, The Netherlands 


\section{Introduction}

International law has a major structural crack: the limited international legal capacity of non-states, ${ }^{1}$ and a high threshold of attribution to states. ${ }^{2}$ In many instances, factual harm cannot be attributed to an actor which is conceptually even able to violate international law. As a consequence, a great deal of international conduct remains unregulated. Harm may be caused in fact, but not necessarily in (international) law. Attribution is a part of the secondary rules on state responsibility. This article argues that the conceptual distinction between primary and secondary rules of international law does not work. The so-called secondary rules of state responsibility, as this paper demonstrates, also regulate international legal capacity. I use the relationship between the concepts of wrongfulness, responsibility and defences as a tool to (i) address certain theoretical misconceptions of international law pertaining to the distinction between the primary and secondary rules; and to (ii) demonstrate how such theoretical misconceptions lead to certain problems in the practical application of international legal regulation. In order to do that, I first need to explain how I understand the nature and method of international law.

Section 2 argues that international legal scholarship should be used as a set of tools for fixing practical problems, but such tools can only be manufactured by thorough doctrinal work. Section 3 explains the overlap between the law of responsibility and legal capacity. Section 4 demonstrates that there is no strict division between the primary and secondary rules of international law, and that these rules should not be read in isolation from one another, or in sequential order. Section 5 analyses the concept of defences-or circumstances that preclude wrongfulness - which make the theoretical distinction between the primary and secondary rules even more blurred. Section 6 concludes with the argument that international legal doctrine has been too preoccupied with attempts to heal certain symptoms of the unclear concept of international legal personality, while the origins of the disease have not been adequately addressed. For example, self-defence against non-state actors, as well as the unclear legal status of Taiwan, Somaliland and even Kosovo, ${ }^{3}$ are ultimately not substantive questions of the law of the use of force and/or the law of statehood. These are eminent conceptual questions of the law governing international legal capacity.

\footnotetext{
1 International Court of Justice (ICJ), Reparation for Injuries Suffered in the Service of the United Nations, Advisory Opinion of 11 April 1949, ICJ Reports 1949, p. 174, at pp. 178-179.

${ }^{2}$ See Military and Paramilitary Activities in and against Nicaragua (Nicaragua v. United States of America), Merits, Judgment of 27 June 1986, ICJ Reports 1986, p. 14, at pp. 64-65, paras. 115 and 116 (the Nicaragua case).

3 See D'Aspremont (2007), Crawford (2006), Vidmar (2013a).
} 


\section{The Nature and Method of International Law}

\subsection{In Defence of Theory and Doctrinal Research}

Even in an age where knowledge utilisation, impact and societal relevance are the driving forces of research, ${ }^{4}$ I strongly believe in the need to invest in theory. We do not know what the future may bring; what factual circumstances may occur in which our theory might solve practical problems. We have all heard about Albert Einstein and the theory of relativity. ${ }^{5}$ Writing about the practical implications of this utterly theoretical work, a physicist has recently stated that next time you take a flight, 'think about Einstein and the GPS tracker in the cockpit, helping the pilots guide you to a safe landing'; namely, 'without the proper application of relativity, GPS would fail in its navigational functions within about 2 minutes' ${ }^{6}$

If a certain anonymous theoretician, working in Zurich and Berlin 100 years ago, ${ }^{7}$ were asked at the time what the impact and societal relevance of his work were, he could not have answered that in hundred years, 3.5 billion air passengers would be flown per year ${ }^{8}$ in aircraft using satellite navigation which would only be able to operate correctly with the application of his theory. Not even Einstein himself could predict the future, so he could not have predicted the full extent of the impact, societal relevance, and knowledge utilisation of his theoretical work.

In international law, theoretical work has the status of subsidiary legal sources. ${ }^{9}$ One could also theorise the question of what theoretical work is in contemporary legal science. ${ }^{10}$ How do I understand theoretical work? In 2015, the President of Sudan, Omar al-Bashir, participated in the summit of the African Union, held in South Africa. ${ }^{11}$ The International Criminal Court (ICC) had previously issued an arrest warrant for him. ${ }^{12}$ But he has immunity as a head of state under customary law. ${ }^{13}$ While the Rome Statute of the ICC overrides such immunities, ${ }^{14}$ Sudan is not a party to it. ${ }^{15}$ Nevertheless, the referral of the Sudan situation to the ICC came by

\footnotetext{
4 As examples see the websites of the Netherlands Organisation for Scientific Research: http://www.nwo. nl/en/policies/knowledge+utilisation, and the Economic and Social Research Council (UK): http://www. esrc.ac.uk/research/evaluation-and-impact/what-is-impact/.

5 For an illuminating contribution on eight ways to see Einstein's theory of relativity see: http://www. livescience.com/48922-theory-of-relativity-in-real-life.html.

${ }^{6}$ C.M. Will, 'Einstein's Relativity and Everyday Life', http://physicscentral.com/explore/writers/will. cfm (year of publication unknown, accessed online in 2016).

7 See 'Albert Einstein-Biographical', http://www.nobelprize.org/nobel_prizes/physics/laureates/1921/ einstein-bio.html.

${ }^{8}$ For comprehensive data see: http://data.worldbank.org/indicator/IS.AIR.PSGR.

9 Statute of the International Court of Justice (1945), Art. 38(1)(d).

${ }^{10}$ For an overview see Orford and Hoffman (2016).

11 See 'Wanted Sudan leader Bashir avoids South Africa arrest', BBC News, 15 June 2015, at http:// www.bbc.com/news/world-africa-33135562.

12 The Prosecutor v. Omar Hassan Ahmad Al Bashir, ICC-02/05-01/09 Pre-trial.

13 See Akande and Shah (2010), p. 820.

14 Rome Statute of the International Criminal Court, A/CONF.183/9 (17 July 1998), Art. 27.

15 For a list of the parties to the Rome Statute see: https://asp.icc-cpi.int/en_menus/asp/Pages/asp_home.aspx.
} 
virtue of United Nations (UN) Security Council Chapter VII Resolution which makes it binding on all states, not only treaty parties. ${ }^{16}$ This is not a place to go into the substantive details of the al-Bashir incident. ${ }^{17}$ My intentions are conceptual in nature. The decision whether or not to arrest al-Bashir-a question of yes or norequires a nuanced prior theoretical work on the relationship between treaty law and customary international law; between the bilateral obligations of two states and multilateral treaty obligations; of the effect of Chapter VII resolutions, Article 103 of the UN Charter; and a number of other doctrinal matters. ${ }^{18}$ Yet, if one presented it like that in purely theoretical terms, at a time when one could not possibly know that al-Bashir would travel to South Africa in the future, impact, societal relevance, and knowledge utilisation would have been difficult to identify. This is again because one cannot predict the future and only a real set of events may someday put flesh on the bones of our theoretical work.

For others, international legal scholarship should be theorised through the perspective of a particular school of social thought. ${ }^{19}$ It is important to theorise international law also from more abstract aspects. But it is wrong to start with international law at an abstract stage. Just as painting does not start with cubism, international law does not start with critical legal studies. A good legal argument does not shy away from the storms of social reality. It goes there, but also safely brings the argumentation back to the formal sources, back to Article 38(1) of the ICJ Statute. As the ICJ put it in South West Africa: 'Law exists, it is said, to serve a social need; but precisely for that reason it can do so only through and within the limits of its own discipline. Otherwise, it is not a legal service that would be rendered'. ${ }^{20}$ Good scholarship may even formally be a subsidiary source of law ${ }^{21}$; it can fix a small but pressing legal problem, and add yet another small piece into the puzzle of the international legal system. And with such a piece, it can further diminish the zone of dangerous ambiguity in international legal regulation.

The United States Chief Justice John G. Roberts, Jr. once sarcastically remarked about contemporary publishing in legal academia: '[T]he first article [you will encounter in a law review] is likely to be [...] the influence of Immanuel Kant on evidentiary approaches in 18th-century Bulgaria, or something, which I'm sure was of great interest to the academic that wrote it, but isn't of much help to the bar' ${ }^{22}$ I share the view that legal scholarship needs less Immanuel Kant in 18th-century Bulgaria and more tool-making for resolving contemporary legal problems, or a better understanding of legal phenomena of the past.

\footnotetext{
16 UNSC Res. 1593 (31 March 2005).

17 De Wet (2015).

18 See the subsequent case of The Minister of Justice and Constitutional Development v. The Southern African Litigation Centre (867/15) [2016] ZASCA 17 (15 March 2016).

19 For an overview of some approaches, such as Foucauldian, Marxian, liberal, Kantian, see, e.g., Aalberts and Golder (2012), Chimni (1999), Carty (2008), Marks (2000), Slaughter (1993), Tesón (1992).

20 South West Africa cases (Liberia v. South Africa, joint with Ethiopia v. South Africa) (second phase), Judgment of 18 July 1966, ICJ Reports 1966, p. 6, at p. 34, para. 49.

21 Cf. supra n. 9.

22 'Women Lead the Way in White-Collar Law', NY Times, 2 April 2013, at http://dealbook.nytimes. com/2013/04/02/women-lead-the-way-in-white-collar-law/?_r=0.
} 


\subsection{International Law as a Tool}

As legal scholars, I believe we are toolmakers. We should be developing the tools to be used by decision-makers and individuals when they need to fix legal problems or address the legal challenges of social reality. Certainly, there is a danger that these tools could be misused by others, as any tool can be misused. A hammer can be used to fix your car or to smash it. We cannot control who will be using the tools we have manufactured, and how. But then, it is also our duty to develop in our scholarship the manuals on the proper usage of our tools and raise our voices when such tools are not used properly.

We also need to know what international law can do at all, and what its limits are-what kind of a tool it is. A sledge hammer may be quite a useful tool for many purposes, but it would certainly disappoint you if you used it in an attempt to fix your precious Swiss watch. Sometimes we hear voices raised about how ineffective international law is, indeed so ineffective that it is not even law. ${ }^{23}$ But then, every time we see a reckless driver speeding on the road, do we start asking ourselves whether Dutch law is actually law properly-so-called? ${ }^{24}$ Do we say that Dutch law, if it is law at all, would cause a collision and lead to fatalities? It is clearly the reckless driver who is to be blamed for such outcomes, and not the law of the Netherlands. Yet, we often try to hold international law to a higher standard than domestic law.

In domestic society, there are several situations in which the law does not always bite. Think of those reckless drivers, of organised crime and the ability of the more powerful to get away with severe breaches of legal rules. ${ }^{25}$ It also needs to be kept in mind that international law has never killed anyone. This is done by people; often but not always by breaching international law, either as individuals or-via attribution - on behalf of states. When we say breaching international law, what exactly do we mean? We often read in the media or hear politicians and the general public saying how conduct $\mathrm{X}$ or $\mathrm{Y}$ was in violation of international law. ${ }^{26}$ But we always need to ask ourselves precisely which legal norm was breached by a certain conduct - was there a legal norm applicable prima facie in the sense of the formal sources of Article 38(1) of the ICJ Statute? Was the legal norm we are talking about even binding on the actor who allegedly breached it? Can the actor involved in the certain conduct under scrutiny even breach international law? Answering these questions will tell us what kind of a tool international law is, so that we do not expect too little of it or, even worse, too much.

This is what I will address in the remainder of my paper. Why do we sometimes have conduct which appears to be wrongful, but is actually not? Why are certain

\footnotetext{
${ }^{23}$ Cf. Austin (1832), p. 117.

${ }^{24}$ Cf. Kleinfeld (2010).

${ }^{25}$ See, e.g., Van Duyne (1996).

${ }^{26}$ Some headlines include: 'Downing of Russian jet "violated international law", BBC News, 24 November 2015, at http://www.bbc.com/news/world-europe-34918051; 'Texas execution "violated international law", UN says', BBC News, 8 July 2011, at http://www.bbc.com/news/world-us-canada14089246; 'US drone war violates international law', RT, 2 July 2016, at https://www.rt.com/op-edge/ 349316-us-drones-civilian-casualties.
} 
actors capable of causing harm internationally, but escape international responsibility? I will question the theoretical division between the primary and secondary rules of international law, the separation of wrongfulness and responsibility, and argue that such divisions are arbitrary and do not work, neither in theory nor in practice.

\section{International Legal Capacity and the Law of Responsibility}

International law is a legal system derived from states. ${ }^{27}$ This is not to say that actors other than states do not exist in this system. ${ }^{28}$ But states are those actors which have full international legal capacity. ${ }^{29}$ This also follows from the formal sources of law: it is states which conclude international treaties in the sense of the Vienna Convention on the Law of Treaties ${ }^{30}$; and it is state practice, combined with opinio juris (again derived from states) which form customary international law. ${ }^{31}$

International treaties can be of various kinds. They can be bilateral, multilateral or indeed so multilateral that they are virtually universal. They can regulate something quite technical and specific, such as the construction of a system of locks on a river in the border area between two states, ${ }^{32}$ or establish something as complex as the UN, ${ }^{33}$ or the European Union (EU). ${ }^{34}$ Treaties between states can thus create international organisations and other legal creatures with their own organs which can also make autonomous decisions, ${ }^{35}$ at least to some extent, and some more than others-depending on what states have agreed to in the underlying treaty. In some instances, we may ask ourselves if states do not sometimes create a Frankenstein over whom they lose control. ${ }^{36}$

\footnotetext{
27 Vidmar (2014), p. 109-110.

28 Ibid.

29 Ibid.

30 Vienna Convention on the Law of Treaties (23 May 1969), 1155 UNTS 331, Art. 1.

31 See the Nicaragua case, supra n. 2, para. 184.

32 See, e.g., Gabčíkovo-Nagymaros Project (Hungary/Slovakia), Judgment of 25 September 1997, ICJ Reports 1997 , p. 7, at pp. 17-18, para. 15.

33 UN Charter (1945).

34 Treaty on European Union (TEU) (2007, consolidated version).

35 See, e.g., UN Charter Arts. 39-42 for legally binding measures of the UN Security Council; and TEU, Arts. 13-22 for the EU institutional arrangement.

36 See, e.g., European Court of Justice, Case 26/62 Van Gend en Loos ECLI:EU:C:1963:1, para. 3, where the Court decided that what is now the EU was not just an ordinary treaty regime of public international law. Rather, it "constitutes a new legal order of international law for the benefit of which the states have limited their sovereign rights, albeit within limited fields, and the subjects of which comprise not only the Member States but also their nationals. Independently of the legislation of Member States, Community law not only imposes obligations on individuals but is also intended to confer upon them rights which become part of their legal heritage. These rights arise not only where they are expressly granted by the Treaty but also by reason of obligations which the Treaty imposes in a clearly defined way upon individuals as well as upon the Member States and upon the institutions of the Community.' See also Guzman (2013), arguing 'States sometimes create their own form of artificial life, the international organization (IO). Dr Frankenstein created his monster in an attempt to improve on a world populated
} 
When the UN Security Council adopts a legally binding resolution, its binding nature is anchored in Chapter VII of the UN Charter which is an international treaty. ${ }^{37}$ Hence, even the law-making powers of the UN can be traced back to states, or more specifically, to the very specific treaty which has been ratified by nearly all states in the world. ${ }^{38}$ At the same time, it is a selection of states which vote in the Security Council; this is not an autonomous organ devoid of state influence. ${ }^{39}$ The General Assembly resolutions are not legally binding, but they may be relevant for the identification of customary international law. ${ }^{40}$ And it is again states which vote in the General Assembly. In a sense, this body may be, inter alia, seen as a provider of secretarial services for the identification of international custom. It is always difficult to identify what states believe for the purposes of opinio juris, but the General Assembly is probably the most prominent place where states go on the record and do so collectively.

In terms of legal capacity, international law-making appears to be a prerogative of states, although sometimes this happens indirectly and through international organisations. ${ }^{41}$ How about law-breaching? Is this also only a prerogative of states? Here, we come to the question of the capacity to commit an internationally wrongful act. In other words, can only an act of state be an internationally wrongful act; and what is an act of state?

Already in 1949, in the Reparations Advisory Opinion, the ICJ acknowledged that rights and duties under international law were not only inherent in states but also in international organisations. ${ }^{42}$ The Court importantly added that this does not mean that the level of these rights and duties is the same as that of states, but that even international organisations have international legal capacity for the purposes of their functioning. The ICJ reasoned: 'The subjects of law in any legal system are not necessarily identical in their nature or in the extent of their rights, and their nature depends upon the needs of the community'. ${ }^{43}$ After establishing that the UN had international personality, the Court continued:

That is not the same thing as saying that it is a State, which it certainly is not, or that its legal personality and rights and duties are the same as those of a State. Still less is it the same thing as saying that it is 'a super-State', whatever that expression may mean. It does not even imply that all its rights and duties must be upon the international plane, any more than all the rights and duties of

\footnotetext{
Footnote 36 continued

only by humans. States create IOs with the hope of enhancing international cooperation beyond what can be achieved by states alone. Like Frankenstein's monster, IOs created by states may behave differently from the way they are expected to. There is always a risk that an IO will impact the system in ways that harm, rather than help, the interests of states. An IO can become a monster.' Guzman (2013), p. 1000.

37 See supra n. 33.

38 For a list of UN member states see: http://www.un.org/en/member-states.

39 UN Charter, Arts. 23-32.

40 See the Nicaragua case, supra n. 2, para. 188.

41 Ibid.

42 Reparation for Injuries Suffered in the Service of the United Nations, supra n. 1.

43 Ibid., p. 178.
} 
a State must be upon that plane. What it does mean is that it is a subject of international law and capable of possessing international rights and duties, and that it has capacity to maintain its rights by bringing international claims. ${ }^{44}$

The rise of international human rights law also gives international legal personality to individuals, ${ }^{45}$ as does international refugee law, ${ }^{46}$ while international criminal law sanctions individuals as perpetrators of war crimes and crimes against humanity. ${ }^{47}$ But we should not forget that even in these instances we still have in the background treaties concluded by states, as well as customary international law which is shaped and formed by states. ${ }^{48}$

In municipal legal systems, we have a difference between human beings and corporations which have legal capacity for different purposes, much in line with what the ICJ pronounced in the Reparations Advisory Opinion. ${ }^{49}$ But then we certainly have other actors involved, such as animals. ${ }^{50}$ A range of legal rules protect them against animal cruelty and regulate hunting. On the other hand, legal rules also regulate liability when animals cause harm. ${ }^{51}$ This, of course, does not mean that a shark would be charged with the crime of murder and be imprisoned for killing a surfer; or that a bear would be charged with animal cruelty and be liable for damages if it attacks one's cattle when looking for food.

Although animals enjoy a level of protection in our human legal systems, their legal capacity is not such that they could be held liable for breaching our laws. ${ }^{52}$ In some circumstances it may be, however, that humans or even corporations, which do have such capacity, would be liable for the conduct of animals. ${ }^{53}$ Factual harm caused by an animal may well be a crime or a tort in law. ${ }^{54}$ Not that of a shark or bear, of course; we will need to attribute that conduct to someone with such a level of legal personality to even have the capacity to commit a crime, or be legally liable under tort law. ${ }^{55}$ In essence, in every legal system actors exist which are capable of

\footnotetext{
44 Ibid., p. 179.

45 See McCorquodale (2004).

46 Convention Relating to the Status of Refugees (1951), Art. 1.

47 Trial of the Major War Criminals before the International Military Tribunal, Vol. 1, Nurnberg 1947, p. 223, recognising that '[c]rimes against international law are committed by men, not by abstract entities, and only by punishing individuals who commit such crimes can the provision of international law be enforced'.
}

48 See the Rome Statute of the International Criminal Court (1998) which has been ratified by 123 states. Art. 5 of this international treaty defines war crimes, crimes against humanity and genocide as crimes for which the Court can-subject to some other conditions-exercise its jurisdiction over individuals.

49 See supra n. 42.

${ }^{50}$ Cf. supra n. 43.

51 In many legal systems, different kinds of animals underlie the distinction between strict liability and negligence. For example, if your pet tiger causes harm, you will be held liable no matter how much precaution you took against this happening. This could be different if such harm were caused by your horse. See, e.g., Van Gerven, Lever and Lauroche (2000), ch. 6.

52 Ibid. See also Posner (2000, reviewing Wise 2000).

53 Ibid.

54 Ibid.

55 See Spencer (2014), p. 324. 
causing factual harm and may even be capable of being harmed themselves, but do not have the legal capacity to be legally responsible for their own conduct. In the end their conduct will be wrongful only if an actor with an adequate level of legal capacity can be made liable for it. Now, I will turn to international law where such liability is called state responsibility and is considered to constitute a body of the socalled secondary rules.

\section{The Problematic Division Between Primary and Secondary Rules}

The primary rules of international law are said to determine which conduct is or is not wrongful, while the secondary rules aim to regulate responsibility for wrongfulness. ${ }^{56}$ In this paper it is submitted that the secondary rules on responsibility, in fact, overlap with the concept of legal capacity. It is thus the law of responsibility which actually determines whether or not we can even identify an actor in a certain conduct with the legal capacity to breach international law. It is not a coincidence that, of all actors capable of causing harm internationally, international law regulates only the responsibility of states ${ }^{57}$ and international organisations. ${ }^{58}$ While there is the very limited category of the international criminal responsibility of individuals, this is a derived concept, dependent on violations of international humanitarian law. ${ }^{59}$ With the partial and conditional exception of international criminal law, it is thus only states and, to a much more limited extent, international organisations which are even conceptually capable of violating international law directly. I will now proceed with the law of state responsibility, yet insofar as certain rules of international law are also applicable to international organisations, the reasoning could be extended to them.

\subsection{What Is an Internationally Wrongful Act?}

The law of state responsibility is said to be secondary in nature because it regulates the consequences of a breach of a legal obligation, while it does not determine whether or not there has been a breach of the underlying primary norm. As the ICJ put it in the Gabčíkovo/Nagymaros case between Hungary and Slovakia:

A determination of whether a convention is or is not in force, and whether it has or has not been properly suspended or denounced, is to be made pursuant to the law of treaties. On the other hand, an evaluation of the extent to which the suspension or denunciation of a convention, seen as incompatible with the

\footnotetext{
56 See the International Law Commission (ILC) Articles on Responsibility of States for Internationally Wrongful Acts (ARSIWA) (2001), ILC Yearbook 2001, Vol. II Part 2. Commentaries, General Commentary, para. 1.

57 Ibid., para. 4(d).

58 See the International Law Commission (ILC) Draft Articles on the Responsibility of International Organisations (DARIO) (2011), ILC Yearbook 2011, Vol. II Part 2.

59 See, e.g., the Statute of the International Criminal Court, Art. 5, which establishes that at present the Court has jurisdiction for: (i) the crime of genocide; (ii) war crimes; and (iii) crimes against humanity.
} 
law of treaties, involves the responsibility of the State which proceeded to it, is to be made under the law of state responsibility. ${ }^{60}$

This is a two-step approach. Wrongfulness is identified under the primary norm - in this case originating in treaty law-and once this has been established, the law of state responsibility is used to determine the consequences of wrongfulness. But the problem is that this approach only works when the conduct can-by definition-only be an act of state. This was precisely the case in the factual circumstances of Gabčíkovo/Nagymaros.

In order to suspend or denounce a treaty, the state needs to act through its organs. ${ }^{61}$ I cannot now suspend a treaty-wrongfully or rightfully-to which the Netherlands is a party. It is inherent in the very concept of the act of treaty suspension that such conduct can only come from a state-otherwise this cannot be a treaty suspension. But not all international conduct is so straightforward. States do not only act through their organs in a sense of Article 4 ARSIWA which reads: 'The conduct of any State organ shall be considered an act of that State under international law, whether the organ exercises legislative, executive, judicial or any other functions $[\ldots],{ }^{62}$

In a number of other situations, a certain conduct may or may not be an act of state, depending on the circumstances. While I cannot suspend a treaty to which the Netherlands is a party, I may be able to put the Netherlands in violation of a treaty, provided that my conduct is attributable to the Netherlands. Contrast Article 4 with Article 8 of ARSIWA: 'The conduct of a person or group of persons shall be considered an act of a State under international law if the person or group of persons is in fact acting on the instructions of, or under the direction or control of, that State in carrying out the conduct'. ${ }^{63}$

This is much more complicated. Unlike in the Gabčíkovo/Nagymaros types of situations, in an Article 8 ARSIWA situation we do not start with the assumption that the conduct at stake was even an act of state. We have conduct which is capable of being internationally wrongful when it can be attributable to a state. Wrongfulness is thus purely notional until it can be proven that the actor responsible for it had the legal capacity to violate international law in general, and that it was bound by the particular rule in question.

In the Nicaragua case, the ICJ had to consider whether the conduct of the Nicaraguan contras was attributable to the United States. ${ }^{64}$ The ICJ established a very demanding threshold by holding that for the United States to incur responsibility, 'it would in principle have to be proved that that State had effective control of the military or paramilitary operations in the course of which the alleged violations were committed'. ${ }^{65}$ Where a state does not have full overall territorial

\footnotetext{
60 The Gabčíkovo/Nagmaros case, supra n. 32, para. 47.

61 ARSIWA, Commentaries, Commentary to Art. 2, para. 2.

62 ARSIWA, Art. 4 (emphasis added).

63 ARSIWA, Art. 8 (emphasis added).

64 The Nicaragua case, supra n. 2, paras. 115 and 116.

65 Ibid., para. 115.
} 
control, it does not incur responsibility if it is 'merely' financing, training, supplying and otherwise supporting rebels in a foreign state. ${ }^{66}$ It needs to be proven that the foreign state had effective control of the operation in which the alleged violations happened. And this may be quite difficult to prove. International responsibility then effectively becomes a question of evidence which may often be unavailable to anyone other than the state trying to escape responsibility. In the Nicaragua case, the ICJ referred to responsibility. I will now demonstrate that the high Nicaragua threshold creates a gap not only in responsibility, it can also mean that the entire conduct was not internationally wrongful.

On 17 July 2014, MH17 was downed over the territory of Ukraine, in the area over which that state does not exercise effective control. ${ }^{67}$ It is believed that the plane was shot down by insurgents fighting against the government of Ukraine, but they are not a state. ${ }^{68}$ Common knowledge tells us that the insurgents are backed by Russia, ${ }^{69}$ but do we have enough evidence to conclude that the rather demanding Nicaragua threshold test for attribution to a foreign state has been met? ${ }^{70}$ It is difficult to speculate. Looking at the problem conceptually, this is not like the suspension of a treaty from Gabčíkovo/Nagymaros. In that case, the treaty could be suspended only because it was an act of state. The question was then whether or not this was done rightfully. But in the case of MH17, a civilian aircraft was shot down and people deprived of their lives regardless of whether or not this was an act of state. The tragic event is a matter of fact and now we need to attach the law to it. This will be an act of state only if the conduct is attributable to a state.

As it is not known whether this was an act of state, we need to start with attribution, which is a part of the so-called secondary rules of state responsibility. The two-step approach and a strict separation of the primary and secondary rules simply do not work. What is more, if the conduct cannot be attributed to either state involved in the situation-Ukraine or Russia-does this mean that they escape responsibility, or indeed that this was not an internationally wrongful act in the first place? Pursuant to Article 2 of ARSIWA, it is the latter. The Article reads: 'There is an internationally wrongful act of a State when conduct consisting of an action or omission: (a) is attributable to the State under international law; and (b) constitutes a breach of an international obligation of the State'. ${ }^{71}$ Article 2 of ARSIWA thus refers us to the rules of attribution which are, however, also a part of the secondary rules on state responsibility. Moreover, it follows from this formulation that until the conduct can be attributed to a state, wrongfulness remains purely notional and as such it is not an internationally wrongful act. This is indeed a structural crack in international law: the limited international legal capacity of non-states and a high threshold of attribution to states.

\footnotetext{
66 Ibid., para. 292.

67 See 'MH17 Malaysia plane crash: What we know', BBC News, 14 October 2015, at http://www.bbc. com/news/world-europe-28357880.

68 Ibid.

69 See Gibney (2015) p. 170.

70 Ibid., pp. 171-172.

71 ARSIWA, Art. 2 (emphasis added).
} 
When deciding that the support of the United States to the Nicaraguan contras fell below the attribution threshold, the ICJ reasoned 'that the contras remain responsible for their acts, and that the United States is not responsible for the acts of the contras, but for its own conduct vis-à-vis Nicaragua'. ${ }^{72}$ But what precisely does it mean when it was said 'that the contras remain responsible for their acts'? ${ }^{73}$ The problem is that their international legal capacity was such that the contras could not even breach many rules of international law. The contras did not have general international legal capacity. Due to the very specific - and from the standpoint of general international law conceptually somewhat peculiar-rules of international humanitarian law, the contras could indeed violate the rules governing noninternational armed conflict. ${ }^{74}$ Any other violations and responsibility under international law remained purely notional, however, and would only 'materialise' if the contras had either become the Government of Nicaragua or created their own state. $^{75}$

The ICJ's reasoning in this part should thus be read very cautiously. The general assumption should not be that somebody is responsible for the internationally wrongful acts: if it is not the United States, it is still the contras. The nature and structure of international law is such that the contras could only violate certain rules of international humanitarian law_or the minimum core of those rules- ${ }^{76}$ but not international law in general. Their acts could therefore have factual effects, but no legal effects in the sense of public international law. The attribution threshold applied in the Nicaragua case made the contras analogous to a wild animal in tort law: it can cause harm in fact, but no one will be liable for it in law. ${ }^{77}$ The animal itself does not have a sufficient level of legal capacity, and if no human were involved, no one would be legally liable for the factually harmful act of a wild bear. $^{78}$

In tort law, human involvement in the life of an otherwise wild animal could lead to strict liability, but no such analogy has been applied by the ICJ to those states which are 'merely' financing, supplying, training and supporting the rebels in another state. If I very much disliked you and a tiger happened to attack you today in the middle of Maastricht, I would not get away with it if the court established that I was merely feeding, training, supplying and supporting that tiger.

Thus far, I have argued that when a certain conduct is not an act of state, it will not be internationally wrongful. This is particularly problematic when states do not act through their organs but by proxy, such as the notorious and mysterious 'little

\footnotetext{
72 The Nicaragua case, supra n. 2, para. 116.

73 Ibid.

74 The Nicaragua case, supra n. 2, para. 219.

75 ARSIWA, Art. 10.

76 See Geneva Conventions (1949), Common Art. 3. International humanitarian law is quite unique in this sense as Common Art. 3 of the Geneva Conventions directly assigns certain rights and duties to nonstate actors. In this very limited framework of the common Art. 3 a non-state actor can violate international (humanitarian) law in its own right.

77 Cf. supra nn. 52-55.

78 Cf. supra nn. 52-55.
} 
green men' without any (Russian) insignia in the territory of Ukraine. ${ }^{79}$ What else the attribution rules can do is that they can identify the prima facie applicable primary rules-again because they identify the actors and different rules may, of course, apply between different actors.

\subsection{Identification of the Underlying Primary Rules}

In the much criticised Tadic judgment, the International Criminal Tribunal for the former Yugoslavia (ICTY) used the attribution rules from the law of state responsibility to determine whether the armed conflict in Bosnia-Herzegovina, which was prima facie of a non-international nature, had been internationalised by the involvement of a foreign state. ${ }^{80}$ This distinction is crucial as quite different rules apply in different types of armed conflict: non-international armed conflict (NIAC) as opposed to international armed conflict (IAC). ${ }^{81}$ To put it simply, the identification of the primary legal rules of armed conflict depended on whether or not certain acts by Bosnian Serbs could be attributed to what was then the Federal Republic of Yugoslavia (FRY).

As this was an ICTY case, it was about the international criminal responsibility of an individual. But it was first necessary to establish what the applicable rules even were in that situation. In order to establish that, the ICTY resorted to the attribution rules. ${ }^{82}$ Criticism of this approach is based on a dogmatic distinction between the primary and secondary rules. Critics say that the secondary attribution rules should not have been applied before wrongfulness was determined under the primary rules $^{83}$ and also that state responsibility should have had no place in a case concerned with individual criminal responsibility. ${ }^{84}$ I strongly disagree with such assertions.

As Judge Cassese subsequently argued, writing as Professor Cassese:

The ICTY admittedly had to establish in Tadić whether the armed conflict in Bosnia was internal or international. However, as no rules of international humanitarian law were of assistance for such determination, the Tribunal explicitly decided to rely upon international rules on state responsibility. ${ }^{85}$

Indeed, how else could the Tribunal determine whether or not a foreign state was sufficiently involved so that an internal conflict had become an international one to which quite different rules apply? One can dogmatically believe that the attribution rules are secondary in nature, but if one interprets that secondary nature as a

\footnotetext{
79 See "Little green men” or "Russian invaders"?', BBC News, 11 March 2014, at http://www.bbc. com/news/world-europe-26532154.

${ }^{80}$ Prosecutor v. Duško Tadić, Case No. IT-94-1-A, Appeals Chamber, Judgment, 15 July 1999, paras. 83-87.

81 Ibid., para. 83 .

82 Ibid., paras. 99-114.

83 See, e.g. Sassòli (2001), p. 325.

84 See, e.g., Milanović (2006), p. 585.

85 Cassese (2007), p. 649.
} 
sequential order, how exactly does one then identify the actors in a certain conduct and thus determine the applicable law-NIAC or IAC?

The second alleged problem in Tadic is that state responsibility was conflated with individual criminal responsibility. ${ }^{86}$ But that is not quite true, either. Even with international criminal responsibility we still have states in the background, as individual crimes are derived from violations of international humanitarian law. ${ }^{87}$ And in international humanitarian law, the identity of the actors determines the applicable law. If we start from the general principle of criminal law nullum crimen nulla poena sine lege, we indeed first need to know the applicable law, we need to identify lex before we can determine crimen and poena. How could the ICTY identify lex in Tadic without resorting to the rules of attribution? Only then did it become clear what international crimes Duško Tadić could have committed. There is no conflation of individual criminal responsibility and state responsibility at stake in this case. It is simply that the attribution rules, which are attached to the law of state responsibility, identify the actors and thus also determine the applicable law. Only once this was clarified under general international law was the ICTY able to proceed with determining individual criminal responsibility.

In international law, we always end up coming back to states. Even individual criminal responsibility does not materialise out of thin air, it is grounded in the formal sources of law; it takes us back to states. The attribution rules under the law of state responsibility may be very important for determining the actors, and then the applicable set of legal rules again crucially depends on the identity of the actors. This is the case even when all actors involved are states.

States A and B may be parties to treaty X, states A and C may be parties to treaty $\mathrm{Y}$ and states $\mathrm{B}$ and $\mathrm{C}$ may be parties to treaty $\mathrm{Z}$. In this system, the scope of legal obligations between states $\mathrm{A}$ and $\mathrm{B}$ is different than between states $\mathrm{A}$ and $\mathrm{C}$, which is again different than that between states B and C. If conduct 1 is contrary to treaty $\mathrm{X}$, the question of whether or not there actually was a breach of an international legal obligation will crucially depend on the identity of the actors involved. If the conduct is attributable to state $\mathrm{C}$, there will be no breach. And even if the conduct were in principle attributable to state $\mathrm{A}$, there will still be no breach where relations between states A and C are concerned. Determining the identity of the actor-which happens via attribution-is thus again of primary importance, as only then does it become clear which rules were applicable - and could be breached-in the first

\footnotetext{
${ }^{86}$ See Application of the Convention on the Prevention and Punishment of the Crime of Genocide (Bosnia and Herzegovina v. Serbia and Montenegro), Judgment of 26 February 2007, ICJ Reports 2007, p. 43, at p. 209, para. 403, especially the following argument: '[T] he Court observes that the ICTY was not called upon in the Tadic case, nor is it in general called upon, to rule on questions of State responsibility, since its jurisdiction is criminal and extends over persons only. Thus, in that Judgment the Tribunal addressed an issue which was not indispensable for the exercise of its jurisdiction. As stated above, the Court attaches the utmost importance to the factual and legal findings made by the ICTY in ruling on the criminal liability of the accused before it and, in the present case, the Court takes fullest account of the ICTY's trial and appellate judgments dealing with the events underlying the dispute. The situation is not the same for positions adopted by the ICTY on issues of general international law which do not lie within the specific purview of its jurisdiction and, moreover, the resolution of which is not always necessary for deciding the criminal cases before it.'
}

87 See supra n. 59. 
place. It is true, however, that sometimes this first step is already implied by the nature of the act. This happens where an act is by definition legal in nature and it is presupposed that the new legal situation could only be created by an act of state in the sense of Article 4 ARSIWA (e.g. treaty suspension). ${ }^{88}$ This is quite different where legal consequences need to be attached to a factual occurrence (e.g. the downing of an aircraft). ${ }^{89}$

\section{Defences: Circumstances That Preclude Wrongfulness?}

The conflation of the so-called primary and secondary rules is perhaps even more directly obvious in the concept of defences, or 'circumstances precluding wrongfulness', as they are termed in ARSIWA. ${ }^{90}$ The first problem is already the phrasing: circumstances precluding wrongfulness. How could the secondary rules of state responsibility preclude wrongfulness if they do not interfere with the determination of wrongfulness? This would seem to be a task for the primary rules. The secondary ones could only preclude responsibility for wrongfulness, but not wrongfulness itself. ${ }^{91}$

ARSIWA then list those circumstances - and indeed conflate some-in which responsibility may be precluded (for example, necessity or force majeure) ${ }^{92}$ and others which actually preclude wrongfulness itself: self-defence pursuant to Article 51 of the UN Charter. ${ }^{93}$ Article 51 is indeed a way out of wrongfulness mandated by Article 2(4) of the UN Charter. It is a legally warranted exception from the original prohibition of the use of force. On the other hand, if a military aircraft violates the airspace of another state due to severe weather conditions or a mechanical failure, this is not a legally warranted exception from the original norm. Wrongfulness is still there, but necessity or force majeure may indeed preclude responsibility for it.

The different types of defence in the chapter on circumstances precluding wrongfulness reflect the typical conceptual distinction between justifications and excuses, as it is known in domestic criminal and tort law. According to J.L. Austin, '[i]n the one defence [...] we accept responsibility but deny that it was bad [justification]; in the other, we admit that it was bad but don't accept full, or even any, responsibility [excuse]'. ${ }^{94}$ Explaining this difference further, Kent Greenawalt

\footnotetext{
88 See supra n. 62.

89 See supra n. 71.

90 ARSIWA, chapter V.

91 Cf. ARSIWA, Commentaries, General Comments, para. 4(a): '[I]t is not the function of the articles to specify the content of the obligations laid down by particular primary rules, or their interpretation. Nor do the articles deal with the question whether and for how long particular primary obligations are in force for a State. It is a matter for the law of treaties to determine whether a State is a party to a valid treaty, whether the treaty is in force for that State and with respect to which provisions, and how the treaty is to be interpreted. The same is true, mutatis mutandis, for other "sources" of international obligations, such as customary international law.'

92 ARSIWA, Arts. 23 and 25.

93 UN Charter, Art. 51.

94 Austin (1956-1957), p. 2.
} 
argues that 'the central distinction between justification and excuse is between warranted action and unwarranted action for which the actor is not to blame' ${ }^{95} \mathrm{~A}$ justification is thus a legally warranted departure from the original prohibition; such as taking life in self-defence. An act may be wrongful prima facie, but a justification takes you out of illegality altogether-it is a circumstance precluding wrongfulness.

Article 51 of the UN Charter is a good example of how a justification may work conceptually in international law. It is included in the Charter-a treaty-and rightly so, but why is it also included in the secondary rules on state responsibility, i.e. in Article 21 of ARSIWA? ${ }^{96}$ When force is used pursuant to Article 51, the use of force is not wrongful in the first place. This logic is actually in line with the title of the chapter circumstances precluding wrongfulness, but the problem is that this title itself is also misleading, which leads to a double confusion.

When we claim to have an excuse, as opposed to a justification, we admit our act was wrongful but we claim we had good reasons for breaching the law; this was the choice of the lesser evil. ${ }^{97}$ The prime example in a municipal setting is emergency drivers, driving too fast when rushing someone to hospital. We admit wrongfulness, we admit we were driving too fast, but also claim that responsibility for wrongfulness should be precluded in this particular circumstance. ${ }^{98}$ This is the logic behind force majeure and necessity in the law of state responsibility. Wrongfulness is still there, and we do not deny it. We just do not accept responsibility for it. ${ }^{99}$ The concept of defences in the law of state responsibility thus mixes together justifications and excuses, places them together under the rules of state responsibility, and labels the defences as circumstances precluding wrongfulness which the rules of state responsibility were not even supposed to do.

In this theoretical exercise, I tried to show that the concepts of wrongfulness, responsibility and defences in international law are actually not separated as strictly as we sometimes believe they are. Or are supposed to believe, on a dogmatic basis: primary and secondary rules are separate. A certain conduct cannot be conceptually wrongful if it cannot be attributed to an actor which can incur international responsibility. There are also some defences that can preclude wrongfulness and others that can preclude responsibility for a wrongful act. And both types are somehow, mysteriously, a part of the secondary rules of state responsibility.

\section{Conclusions, Deficiencies and Hypotheticals}

The distinction between primary and secondary rules is arbitrary and confusing. Many rules from the law of state responsibility are also found in the so-called primary rules, and it is not entirely clear what these rules are doing in the secondary rules which are not supposed to regulate wrongfulness itself, but only responsibility

\footnotetext{
95 Greenawalt (1984), p. 1927.

96 ARSIWA, Art. 21.

97 Cf. Botterell (2009), p. 172.

98 Lowe (1999), p. 410.

99 Ibid.
} 
for it. Perhaps the conflation of such concepts is not accidental, as it is impossible to separate the concepts of legal responsibility and legal capacity for wrongdoing.

Article 4 of ARSIWA is concerned with conduct which is by definition an act of state. ${ }^{100}$ If the conduct is in breach of a legal obligation of this state, it is internationally wrongful and the state will incur responsibility. But this only works because the conduct and the act of state are the same thing. Article 8 of ARSIWA is concerned with conduct which may or may not be an act of state. If it is an act of state, the next question is whether the state breached its international legal obligation. If so, it incurs responsibility. But the trick is that it is again the law of responsibility which determines whether a certain conduct was an act of state, and the law of responsibility may indeed also identify the applicable legal obligation. We return in a circle.

Pursuant to Article 2 of ARSIWA, if a certain conduct was not an act of state, this is not a way out of responsibility, but a way out of wrongfulness altogether. ${ }^{101}$ Namely, if we cannot attribute a certain conduct to any state, we can try with an international organisation, and if even that fails (as international organisations have fewer legal obligations than states anyway), we are left with no actor whose conduct is conceptually even capable of being an internationally wrongful act.

This theoretical exercise resonates in a number of difficult practical issues. I have mentioned the Tadić case where the secondary rules determine which primary rules were applicable in the first place, as well as MH17 in which wrongfulness depends on attribution. We do not know whether there was any wrongdoer under international law, or what the internationally wrongful act was, before we can determine who is responsible.

At the beginning, I argued that one cannot predict the future and what legal problems may arise someday. ${ }^{102}$ Factual and legal situations that may seem to be rather theoretical today could solve difficult international problems tomorrow. ${ }^{103}$ For example, if Taiwanese forces shot at a Philippine gunboat would that act be attributable to Taiwan? How so, if Taiwan is not a state? ${ }^{104}$ Would it be attributable to China? How so, if China does not have effective control over Taiwan? Would an armed attack on Taiwan constitute the use of force in the sense of Article 2(4) UN Charter or customary international law? ${ }^{105}$ Would it actually be use of force against China if carried out by a third state? To whom are the intrusions by rebels from Somaliland into Ethiopia attributable? And indeed the actions of the rebels in Eastern Ukraine? ${ }^{106}$

These are only some possible questions that are affected by the legal problems I have presented here. They are eminent problems of attribution and legal capacity. Ultimately, such questions decide which primary rules are applicable in the first

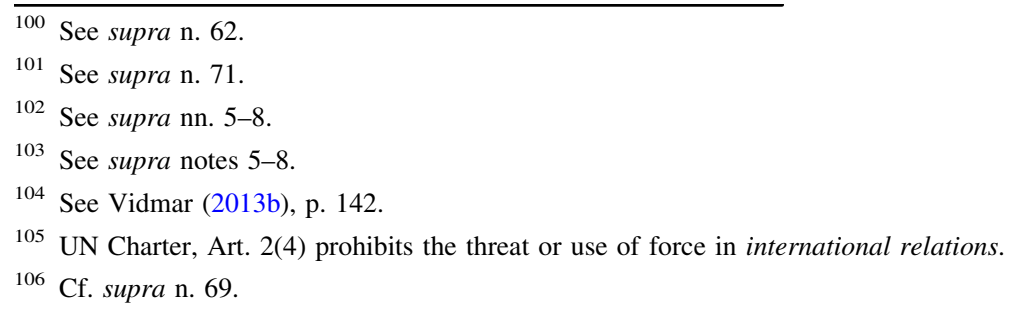


place. Does the use of force from the territories of Somaliland or Taiwan fall within the purview of Article 2(4); is the right of self-defence triggered in the sense of Article 51; and against whom? Which international legal norms, if any, were actually breached when MH17 was downed?

In international legal scholarship, many suggestions have been made to address the symptoms of this underlying disease of international law. Some suggestions are more plausible than others. There is much discussion on the right to self-defence against non-state actors and on the so-called unable and unwilling doctrine. ${ }^{107}$ Do we really want to go down this road and further complicate the substantive rules on the use of force? Are the problems of Taiwan, Somaliland and even Kosovo really problems of the law of statehood? Are these not actually problems of the unclear concept of international legal capacity?

Scholarship is perhaps too focused on addressing certain symptoms of the bigger conceptual problem. And this is: international legal responsibility and thus the capacity for wrongdoing is a prerogative of states, while the attribution threshold of the conduct of non-state entities to states is very high. And while in 1949 the ICJ introduced the sliding-scale principle to the concept of international legal personality, ${ }^{108}$ we still do not know how exactly that sliding scale operates.

Open Access This article is distributed under the terms of the Creative Commons Attribution 4.0 International License (http://creativecommons.org/licenses/by/4.0/), which permits unrestricted use, distribution, and reproduction in any medium, provided you give appropriate credit to the original author(s) and the source, provide a link to the Creative Commons license, and indicate if changes were made.

\section{References}

Aalberts T, Golder B (2012) On the uses of Foucault for international law. Leiden J Int Law 25:603-608 Akande A, Shah S (2010) Immunities of state officials, international crimes, and foreign domestic court. Eur J Int Law 21:815-852

Austin J (1832) The province of jurisprudence determined. In: Rumble W (ed). Cambridge University Press, Cambridge, 1995

Austin JL (1956-1957) A plea for excuses: the presidential address. Proc Aristot Soc 57:1-30

Botterell A (2009) A primer on the distinction between justification and excuse. Philos Compass 4:172-196

Carty A (2008) Marxist international law theory as Hegelianism. Int Stud Rev 10:122-125

Cassese A (2007) The Nicaragua and Tadić tests revisited in light of the ICJ judgment on genocide in Bosnia. Eur J Int Law 17:649-668

Chimni BS (1999) Marxism and international law: a contemporary analysis. Econ Political Weekly 34:337-349

Corten O (2016) The 'unwilling or unable' test: has it been, and could it be, accepted? Leiden J Int Law 29:777-799

Crawford J (2006) The creation of states in international law. Oxford University Press, Oxford

De Wet E (2015) The implications of President Al-Bashir's visit to South Africa for international and domestic law. Int J Criminal Justice 13:1049-1071

D’Aspremont J (2007) Regulating statehood: the Kosovo status settlement. Leiden J Int Law 20:649-668

Gibney M (2015) The downing of MH17: Russian responsibility? Hum Rights Law Rev 15:169-178

107 See Corten (2016), p. 777.
${ }^{108}$ Cf. supra nn. 1 and 44. 
Greenawalt K (1984) The perplexing borders of justification and excuse. Columbia Law Rev $84: 1897-1984$

Guzman A (2013) International organizations and the Frankenstein problem. Eur J Int Law 24:999-1025

Kleinfeld J (2010) Skeptical internationalism: a study of whether international law is law. Fordham Law Rev 78:2451-2530

Lowe V (1999) Precluding wrongfulness or responsibility: a plea for excuses. Eur J Int Law 10:405-411

Marks S (2000) The riddle of all constitutions. Oxford University Press, Oxford

McCorquodale R (2004) An inclusive international legal system. Leiden J Int Law 17:477-504

Milanović M (2006) State responsibility for genocide. Eur J Int Law 17:553-604

Orford A, Hoffman F (2016) The Oxford handbook of the theory of international law. Oxford University Press, Oxford

Posner R (2000) Animal rights. Yale Law J 110:527-541

Sassòli M (2001) The legal qualification of the conflict in the former Yugoslavia: double standards or new horizons for international humanitarian law? In: Yee S, Tieya W (eds) International law in the postCold War world: essays in memory of Li Haopei. Routledge, London, pp 307-333

Slaughter AM (1993) International law and international relations theory: a dual agenda. Am J Int Law 87:205-239

Spencer J (2014) Civil liability for crimes. In: Dyson M (ed) Unravelling tort and crime. Cambridge University Press, Cambridge, pp 304-329

Tesón F (1992) The Kantian theory of international law. Columbia Law Rev 92:53-102

Van Duyne PC (1996) Organized crime, corruption and power. Crime Law Soc Change 26:201-238

Van Gerven W, Lever J, Lauroche P (2000) Tort law. Hart, Oxford

Vidmar J (2013a) Democratic statehood in international law: the emergence of new states in post-Cold War practice. Hart, Oxford

Vidmar J (2013b) States, governments and collective recognition. Chin (Taiwan) Yearb Int Law Relat 31:136-159

Vidmar J (2014) Protecting the community interest in a state centric legal system: the UN Charter and certain norms of 'special standing'. In: Benedek W et al (eds) The common interest in international law. Intersentia, Cambridge, pp 109-126

Wise S (2000) Rattling the cage: toward legal rights for animals. Perseus Books, Cambridge 